あるかすしれない.

\author{
参考文献
}

1) Northrop Aircraft, INC.: Dynamics of the Air- frame, D. D. C. Report, AD 11366, (1952).

2）吉武幸夫ほか 2 名: 動安定風䏤試験の 1 万法について, 飛行機シンポジゥム講演集，(1970/11)， p. 21-22.

3）宮川洋ほ加 2 名: 不規則信号論之動特性推定, コロナ 社.

\title{
遷音速風胴および超音速風胴における動安定試験法とその結果* \\ Techniques for Measurement of Dynamic Stability Derivatives and \\ Test Results in Transonic and Supersonic Wind Tunnels at NAL
}

\author{
高 島 一 明** \\ Kazuaki TAKASHIMA
}

\begin{abstract}
Longitudinal dynamic stability derivatives of firstly a rocket configuration model at Mach numbers from 0.6 to 3.0 and secondly several airplane configuration models at Mach numbers from 1.5 to 2.25 were measured by the forced-oscillation technique in the transonic and the supersonic wind tunnels at NAL. The static stability derivatives measured by dynamic test coincided with those measured by static test. The dynamic stability derivatives, on the other hand, showed themselves being of fairly large values compared with calculated ones.

In addition to the test results, some details of the test equipments and the error analysis for the data reduction system are included. It is shown by this error analysis, that as the output of the balance is decomposed by the resolver into the static and the dynamic derivative components, the latter is very much influenced by the former and that the interference factor can be obtained by the data of wind off condition tests.

Also presented are the damping derivatives in roll, which are measured by another test rig, and which agree precisely with calculated values.
\end{abstract}

\section{1. まえがき}

動安定微係数で表現される動的な空気力は静的な空 気力に比して一般に小さく，測定も困難であるが，航 空機，飛しょう体の安定性，操縦性を考える際には不 可欠の要素である. 動安定微係数を得るには 3 種の方 法が考えられる、第 1 は理論的方法（実験式を含む） であり，第 2 は風胢等での試験1,2)，第 3 は実機また は小型模型住よる自由飛行試験である，各方法はそれ ぞれ得失を持っており，たとえば理論的方法は便利で あるが簡単な模型形状に限られ，また遷音速頒域では 非常に制約をうける. 風胴での動的武験は模型形状の

* 昭和 46 年 7 月 1 日原稿受理

** 航空宇宙技術研究所
制限は小さいが相似パラメータに難点があり，自由飛 行試験は理想的だが模型形状の変化を容易にできな い，適当な試験場所が必要等の欠点を持っている.

風胴におりる動的試験法についての記述は多いが大 別すると模型に全自由度の運動を絔す風䏤内での自由 飛行試験之，若干の自由度に制限する場合とがある. 後者はさらに, 許された自由度での運動即ち変位を測 定する自由振動法と，模型に加わる力またはモーメン トを測定する強制振動法とにわけられる.

ここでは航技研の遷音速，超音速の大型風胴におい て全機模型の動安定試験を行なうために開発された強 制振動による 1 自由度の縦摇れ試験法と，強制回転に よる横罟れ試験法について原理, 方法, 測定誤差, 結 果等について述べる.

\section{2. 記 号}

$c$ : 天秤固有の減衰係数

$d:$ 模型の胴体直径

$E, E^{\prime}:$ 信号電压

$I:$ 模型の慣性能率

$K:$ 天秤固有のばね定数

$k:$ 無次元振動数, $\omega l / 2 \mathrm{~V}$ または $\omega d / V$

$l$ : 基游長

$M:$ マッハ数

$M_{0}$ : 模型に加わっている振動モーメントの振幅

$Q:$ 動圧

$S:$ 基準面積，翼面皘または胴体断面皘

$t:$ 時間

$V:$ 風速

$\varepsilon, \varepsilon^{\prime}:$ 漂遊容量による干涉係数

$\theta:$ 振動変位角

$\lambda:$ 位相角

$\tau: l / 2 V$ または $d / V$

$\phi:$ レゾルバの取り付け角度誤差 


\section{$\omega$ : 角振動数}

添字

$j:$ 虚部

$R i, R 1, R 2$ : レゾルバの入力, 第 1 出力. 第 2 出力

$r$ : 実部

$w f, w n:$ 無風時, 通風時

\section{3. 原理, 方法, 测定誤差}

3.1 原理 模型をある一定の迎角で風胴内に支特 し，その迎角を中心として縦摇れ微小振動を与えた場 合の運動方程式を考える，模型の運動は $Y$ 軸まわり の 1 自由度の回転振動で，加わるモーメントとしては 慣性力，空気力，天秤からの機械力，重力，強制力に よるものが考えられる.とのうち静的な状態であ作用 しているモーメントは天秤，スティングの支待力と平 衡しているから運動方程式では考える必要はなく，重 力によるあのは小さいから無視すると

$$
\begin{aligned}
& I \ddot{\theta}+c \dot{\theta}+K \theta-Q S l\left(C_{m \theta} \theta+\tau C_{m} \dot{\theta} \dot{\theta}+\tau^{2} C_{m} \ddot{\theta} \ddot{\theta}\right) \\
& \quad=M_{0} e^{j \omega t}
\end{aligned}
$$

定常解 $\theta=\theta_{0} e^{j(\omega \ell-\lambda)}$ を代入し，実部と虚部にわけて 整理をし，無風時の試験結果を考えると

$$
\begin{aligned}
C_{m} \theta & -\omega^{2} \tau^{2} C_{m} \ddot{\theta} \\
= & \frac{-1}{Q S l}\left\{\left(\frac{M_{0} \cos \lambda}{\theta_{0}}\right)_{w n}-\left(\frac{M_{0} \cos \lambda}{\theta_{0}}\right)_{w f}\right\}
\end{aligned}
$$

$$
\left.C_{m \dot{\theta}}=\frac{-1}{Q S l \tau}\left\{\left(\frac{M_{0} \sin \lambda}{\theta_{0} \omega}\right)_{w \pi}-\left(\frac{M_{0} \sin \lambda}{\theta_{0} \omega}\right)_{w f}\right\}\right)
$$

となり，静安定微係数とともに動安定微係数がえられ る. $C_{m \dot{\theta}}$ は $C_{m q}$ と $C_{m \dot{\alpha}}$ の和で両者を分離して湘定す ることはこの場合できない.

3.2 万法と試験装置第 1 図は緹摇れ試験用ステ ィングと天秤である、スティング内にある小型大馬力 の駆動モータの回転は，はずみ車，電磁クラッチ，駆 動軸をへて先端のクランクに伝えられる.クランクは 天秤内のスコッチ・ヨーク部之組み合って天秤駆動片 に往復運動を与える，クランクを交㓏するととによっ て振動振幅は $0.5^{\circ}, 1^{\circ}, 2^{\circ}$ と可変である.ささらにステ ィング内にはデータ処理に必要なレゾルバ2こ，タコ メータ等が装備されるととすに風胴実験をやりやすく するための模型中立位直設定機檴がある．模型に与え る強制振動を停止したとき模型はある振動角で停止す るがとの機構を働かすととによって振動角零の位置， すなわちある中心迎角の位直に自動的に設定できる.

天秤の駆動片は振動中心まわりに既定の振幅で振動 し，モーメントビームを介して模型に振動を与える. モーメント・ビーム部に貼り付けられた半導体需みゲ ージによって模型に働くモーメントが振動中心まわり の值として測定されるようになっている゙．変位は模

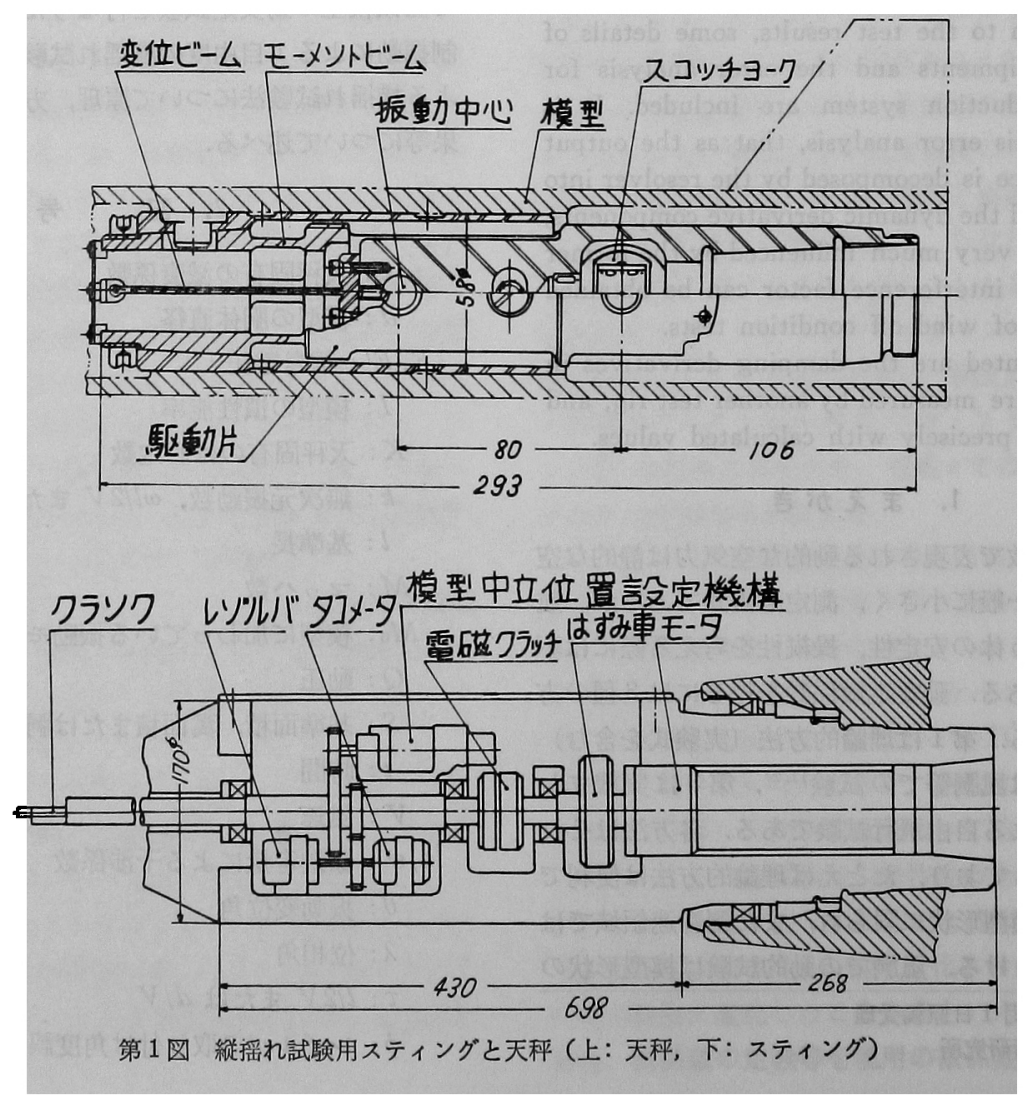

(576) 
型と固定部間をつなぐ板ばねのたわみから求められ る.

この天秤〜スティング系では細長比の大きい模型 で，基準点（振動中心）を前の方に极いた試験住実行 不可能な場合がある，適当な強度を持った模型で基準 点位置が全長の中心にあり，10の振動振幅を与える とすれば実験可能な細長比の最大值は約 10 である.

3.3 計测装置 計測系は零位法的なもの 法的なあの ${ }^{6)}$ があり後者の方が簡単であり，また通風 時間の関係ああっててれを採用した．第 2 四はブロッ ク図である. 模型におりる振動的なモーメント，変位 は天秤で検出され，その信号は增幅後再びスティング 内に送られ、レゾルバの入力となる。 このときの信号 は，例えばモーメントについては

$$
E_{R i}=A\left[a_{0}+\sum_{n=1}^{\infty} a_{n} \sin \left(n \omega t+\lambda_{n}\right)\right] \sin \omega_{c} t
$$

である. $A$ は增幅度， $a_{0}$ はトリムされていない空気 力, 重力による静的モーメントを表わす． $a_{1}$ は基本 振動数のモーメント・ベクトルの大きさで (1),(2) 式の $M_{0}$ であり $I, K, c, C_{m \theta}, C_{m \dot{\theta}} \cdots \cdots \cdot$ によって変化す る. $\omega_{c}$ は搬送波の角周波数である.

レゾルバは駆動軸と同じ回転数で回転しているか ら，振動数と同じ周波数の信号で上記の入力を変調す るととになる. したがってレゾルバの 2 この出力の形 は

$$
\left.\begin{array}{c}
E_{R 1}=A\left[a_{0}+\sum_{n=1}^{\infty} a_{n} \sin \left(n \omega t+\lambda_{n}\right)\right] \\
\times \sin \omega t \sin \omega_{c} t \\
E_{R 2}=A\left[a_{0}+\sum_{n=1}^{\infty} a_{n} \sin \left(n \omega t+\lambda_{n}\right)\right] \\
\times \cos \omega t \sin \omega_{c} t
\end{array}\right\}
$$

この信号はレゾルバを基準とした直角座標系における 信号ベクトルの横座標, 叙座標の值に比例した信号を 含んでいて，それが求める值である.

復調器を通過させて搬送波を除去し，沪波器で直流 分のみをとると上の二つの信号は

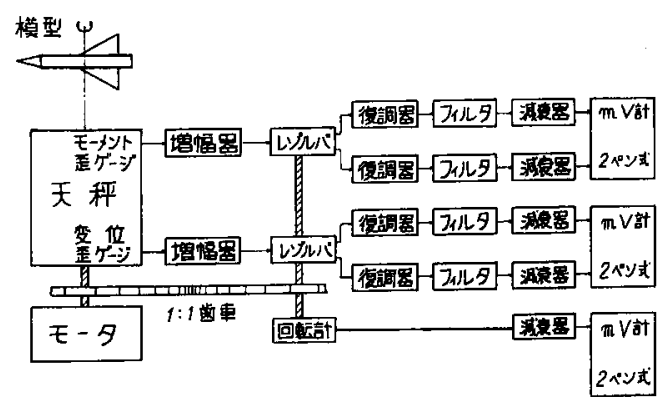

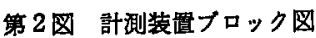

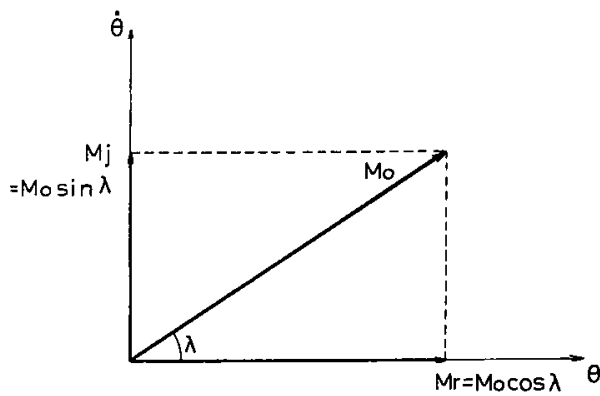

第3困ベクトル関係図

$$
\bar{E}_{R 1}=0.5 A a_{1} \cos \lambda_{1}
$$$$
\bar{E}_{R 2}=0.5 A a_{1} \sin \lambda_{1}
$$

となり，求める值が得られる。一は搬送波を除去し， 平均値をとった意味である.

変位信号についてる同様な結果を得るが $\lambda_{1 \theta}=0$ にな るよう，レゾルバの取り付け位置を調整してある．ま た, 変位とモーメント各チャンネルのレゾルバ取り付 け位置は同じになるようにしてあるから，モーメント の 2 つの出力信号のうち一方は $\theta$ 亿，他方は $\dot{\theta}$ に比例 した信号となっている. 第 3 図にその関係を示す. 角 振動数 $\omega$, 動圧 $Q$ を別に求めれば $(2)$ 式の右辺は決定 され，静安定微係数とと屯に動安定微係数が得られる。

3.4 䛠差 $^{7)}$ モーメント信号系のレゾルバ取り付け 位置について考えて見る．実際の取り付け位㯰は理想 的な場合からすてしずれており，また出力側コイル間 の直交性にあ誤差がある.さらに $1 \mathrm{kHz}$ 程度の搬送波を

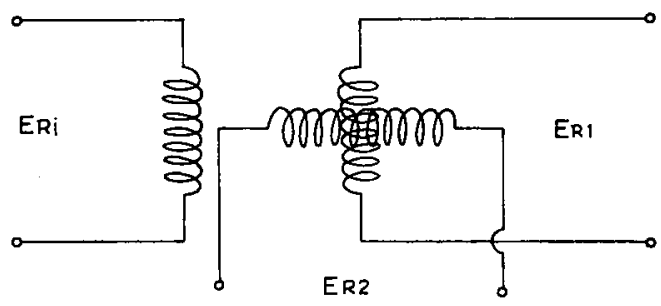

(a) 理想的奆埸合

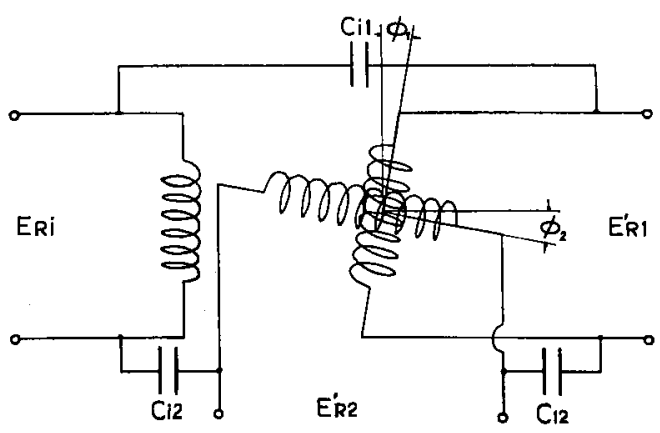

$\phi_{2}=\phi_{1} \cdot \phi^{\prime}$

(b) 実際の埸合 
使用しているから, 各配線部, 機器内での漂遊容量の影 響が考えられる．第 4 図はこの状態を説明したすので ある.したがって（4)式は次のように書くべきである.

$$
\left.\begin{array}{l}
E_{R 1^{\prime}}=E_{R i} \sin \left(\omega t+\phi_{1}\right)+\varepsilon_{1} E_{R i}+\varepsilon_{1}{ }^{\prime} E^{\prime}{ }_{R 2} \\
E_{R 2^{\prime}}=E_{R i} \cos \left(\omega t+\phi_{2}\right)+\varepsilon_{2} E_{R i}+\varepsilon_{2}{ }^{\prime} E_{R 1^{\prime}}{ }^{\prime}
\end{array}\right\}
$$

$\phi_{1}, \phi_{2}$ はレゾルバの备ロータの取り付け角度を表わ し， $\varepsilon_{1}, \varepsilon_{2} \ldots \ldots$ は漂遊容量による影響を示す.とれら の量はいずれす小さい量である.（5)の右辺の $E_{R{ }^{2}}$ ， $E_{R 1}{ }^{\prime}$ の代わりに $E_{R 2}, E_{R 1}$ を用いて計算するととに し，搬送波除去後の長時間平均をとると

$$
\left.\begin{array}{l}
\bar{E}_{R 1^{\prime}}=0.5 A a_{1} \cos \lambda_{1}+0.5 A a_{1}\left(\phi_{1}+\varepsilon_{1}{ }^{\prime}\right) \\
\times \sin \lambda_{1}+\varepsilon_{1} A a_{0} \\
\bar{E}_{R 2^{\prime}}=0.5 A a_{1} \sin \lambda_{1}+0.5 A a_{1}\left(-\phi_{2}+\varepsilon_{2}{ }^{\prime}\right) \\
\quad \times \cos \lambda_{1}+\varepsilon_{2} A a_{0}
\end{array}\right\}
$$

この値の無風時, 通風時の差をとり前と同じようにし $\tau$

$$
\begin{aligned}
& -\frac{\left[\bar{E}_{R 1}{ }^{\prime}\right]_{w n}-\left[\bar{E}_{R 2}\right]_{w f}}{0.5 A Q S l \theta_{0}}=C_{m \theta}-k^{2} C_{m} \ddot{\theta} \\
& +k\left(\phi_{1}+\varepsilon_{1}^{\prime}\right) C_{m} \dot{\theta}+\frac{2 \varepsilon_{1}}{\theta_{0}} C_{m 0} \\
& -\frac{\left[\bar{E}_{R 2}\right]_{w n}-\left[\bar{E}_{R 2}\right]_{w f}}{0.5 A Q S l \theta_{0} k}=C_{m} \dot{\theta}+\left(C_{m \theta}\right. \\
& \left.-k^{2} C_{m} \ddot{\theta}\right) \frac{\left(-\phi_{2}+\varepsilon_{2}^{\prime}\right)}{k}+\frac{2 \varepsilon_{2}}{\theta_{0} k} C_{m 0}
\end{aligned}
$$

つまり右辺の測定值は求めようとする真值とその他の 值による干㽔を含んでいる．てれは静的な 6 分力試験 であ常に問題になることである. 無次元振動数 $k$ は遷 音速，超音速の試験ではよ゙うしてあ小さくなってくる から（7）の第 2 式，第 2 ，第 3 項はある程度有意の蛽 差を $C_{m \dot{\theta}}$ の測定值に与える. 対称模型の $\alpha=0$ の場 合の試験では，（7）の第 3 項は考えなくてよく，結局

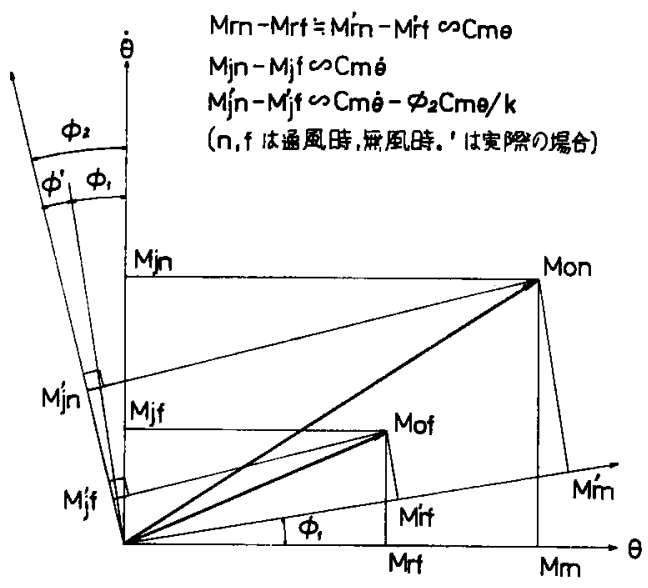

第 5 因 実際の場合のベクトル関係

$$
\begin{aligned}
& \left(C_{m \theta}-k^{2} C_{m} \ddot{\theta}\right)_{\text {meat }} \fallingdotseq\left(C_{m \theta}-k^{2} C_{m} \ddot{\theta}\right)_{\text {true }} \\
& \left(C_{m} \dot{\theta}\right)_{\text {mea }} \fallingdotseq\left(C_{m \dot{\theta}}\right)_{\text {true }}+\frac{\left(-\phi_{2}+\varepsilon_{2}^{\prime}\right)}{k} \\
& \quad \times\left(C_{m \theta}-k^{2} C_{m} \ddot{\theta}\right)_{\text {true }}
\end{aligned}
$$

となり，静安定微係数 $C_{m \theta}$ 力゙動安定微係数の湘定值に 大きな干涉を与えることがわかる. 第 5 図は，理想的 な場合の第 3 困に対応するとの場合のベクトル困であ る.

(8) 式の干涉係数 $\left(-\phi_{2}+\varepsilon_{2}^{\prime}\right)$ は次のようにして求 められる. 無風時にいくつかの既知の慣性能率 $I_{n}$ に 対する振動試験を行ない，レゾルバの第 2 出力を求め ると(6)から

$$
\begin{gathered}
\frac{2}{A \theta_{0}}\left\{\left[\bar{E}_{R 2 n^{\prime}}\right]_{w f}-\left[\bar{E}_{R 21}\right]_{w f}\right\} \\
=\left(-\phi_{2}+\varepsilon_{2}\right)\left[-I_{n}-\left(-I_{1}\right)\right] \omega^{2} \\
n=2,3, \cdots \cdots N
\end{gathered}
$$

この式で $\left(-\phi_{2}+\varepsilon_{2}{ }^{\prime}\right)$ 以外はすでに求められている既 知量であり，干渉係数を求めることができる.

また，一定の慣性能率 $I$ と， tare damping $c$ 少変 化しない程度の振動数範囲で，振動数をかえたいくつ かの試験結果を用いても）9）式と同様な式

$$
\begin{gathered}
\frac{2}{A}\left\{\left[\bar{E}_{R 2 n^{\prime}}\right]_{w \rho}-\left[\bar{E}_{R 21}\right]_{w f}\right\} \fallingdotseq c \theta_{0}\left(\omega_{n}-\omega_{1}\right) \\
+\frac{2}{A}\left(-\phi_{2}+\varepsilon_{2}^{\prime}\right)\left\{\left[\bar{E}_{R 1 n^{\prime}}\right]_{w f}-\left[\bar{E}_{R 11^{\prime}}\right]_{w f}\right\} \\
n=2,3, \cdots \cdots N
\end{gathered}
$$

が得られ $N \geqq 3$ であれば $c$ と干涉係数 $\left(\phi_{2}+\varepsilon_{2}^{\prime}\right)$ を同 時に求めることができる.

要音速風胴，超音速風胴の各動安定試験装置に対し て干涉係数を求めたところ，遷音速風胴の場合は -0.144, 超音速風胴の場合は 0.0209 であった. とれは レゾルバ取り付け角度に換算するとそれぞれ $-8^{\circ} 17^{\prime}$, $1^{\circ} 12^{\prime}$ に相当する．超音速風胴の試験装置については 十分な時間と労力を使ってレゾルバ取り付り位置を調 整したが要音速風胴の場合その余裕がなかったため， このように大きい值を示している，なお，1゚以下に調 整するととは信号／雑音比等多くの問題があり非常に 困難である.

ほかに $C_{m 0}$ による影響，較正の方法等の問題もあ るが省略する.

\section{4. 試験 結果}

第 6 困は器，超音速にわたって緃摇れ動安定試験を 行なったロケット模型の外形図である. 飛しょう試験 用のすのに比べて細長比が小さく，翼は大きい，基準 点は全長に対して先端加ら 63.9\% の位直にある. 翼 は先を切った三角翼で前縁後退角 $25^{\circ} 28^{\prime}$ ，前緣は頂角 


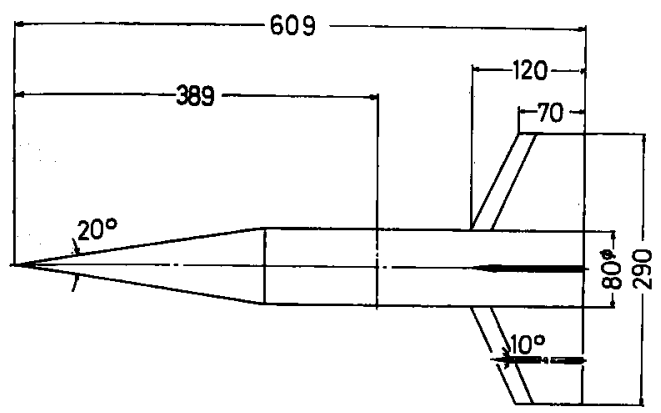

$9926-B$

第 6 図 ロケッ卜模型 (9926 B) 外形

$10^{\circ}$ のくさびであり，他は平板である．胴体は頭部が 半媔角 $10^{\circ}$ の円錐で後部は円柱体である. 第 7 図はこ の模型の動安定試験結果で $M \leqq 1.4$ は遷音速風䏱8”, $M \geqq 1.5$ は超音速風胴 ${ }^{9}$ 亿おりる試験である. 第 7 図 （a）は後方加ら見て翼の配列が+になっている場合， 第7図（b)はメになっている場合の試験結果である. いずれの場合す静安定微係数は静的試験から得たもの とよく一致している．しかしょく見ると $0.95<M<$ 1.2 の䇢围では静的試験で得た值がやや大きくなって おり，また $M=1.05$ 付近の静的試験值，動的試験值 とも低い值を示す谷の部分が存在している. ことでデ 一タの大小を言うのは 一 $C_{m a}$ または $-\left(C_{m q}+C_{m \alpha}\right)$ に ついてであり，静的または動的に，より安定であると いう意味で使用する.

動安定微係数はすでに述べた静安定微係数による影 響を差引いた補正值とそうでない未補正值を第 7 図 （a）に示した．透音速風胴で行なった試験では干渉係 数が大きく，未補正值は動的に不安定な值を示してい る. 補正されたものは超音速風胴㑡のデータ之滑らか につながっていてデータの質は向上していると考えら れる. 補正值は推定值とほほ同し变化をマッハ数に対 して示しているが，推定値よりかなり大きい．また翼 位置が×状態のものが+状態の場合より大きい值を示 している. 推定値は

$$
C_{m q}+C_{m \dot{\alpha}}=-\left(l_{e} / d\right)^{2} C_{N \alpha}
$$

で求めた ${ }^{10)}$ ）ただしlは基準点から模型後端までの 距離, $C_{N a}$ は静的風胴試験少ら得た揚力傾斜係数で ある. 実験值は模型の強制振動数によってかなり変化 があり，第 8 図はそれを示す．静安定微係数は無次元 振動数 $k$ の小さい場合に静的試験值より小さくなり， その後 $k$ の増加ととあに大きくなるが変化程度は小さ い. 動安定微係数は $M=0.6 \sim 1.4$ の場合， $k$ の小さ い所で大きな変化を示している．との理由は空力的な もののほかに測定上のものが考えられる. $k$ が小さい ときは動的な空気力は非常に小さいわけであり，その 值を測定してさらに小さい $k$ の值で割ることからおこ
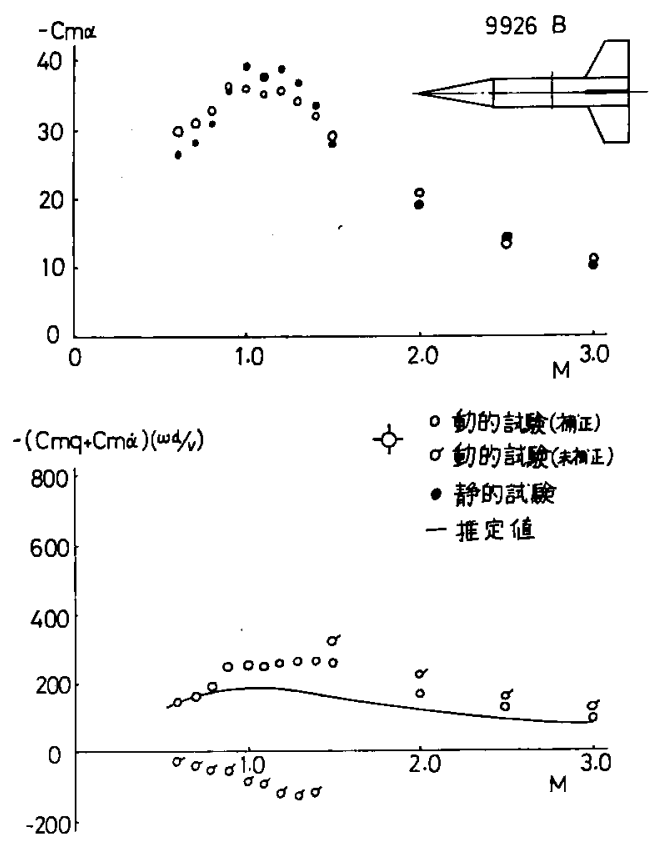

(a) $9926 \mathrm{~B}$ 試験結果
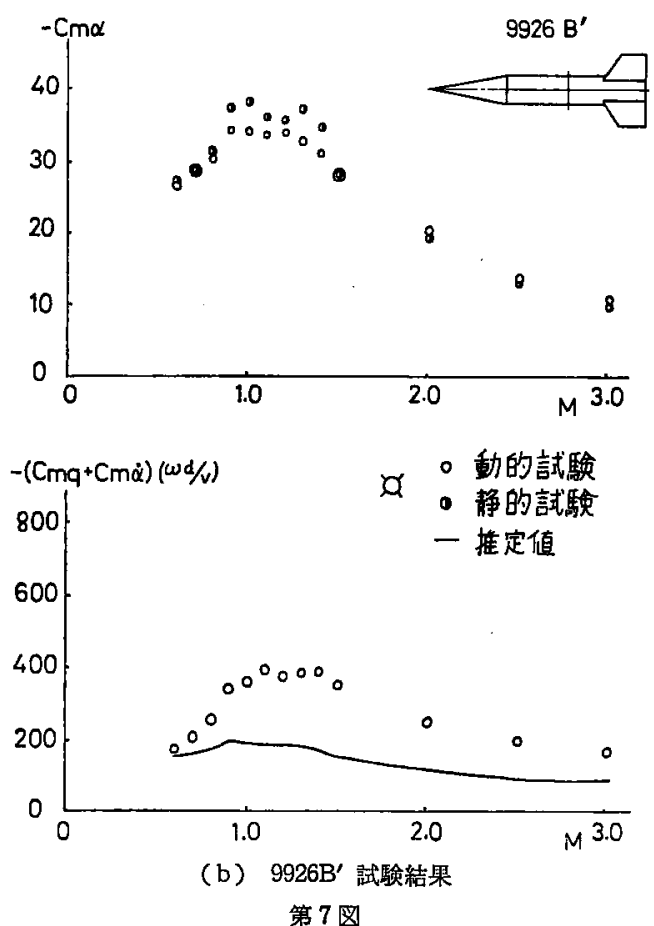

る現象で，ちょうど静的風胴試験の際に，迎角の小さ い所で空力中心位置を求めると著しく異なった值が得 られるととと同じである.したがって第 7 図の場合は 各マッ八数に扔いて実験時の最大の $k$ の值に相当する 微係数の值をプロットしてある.さらに大きい $k$ の值 で試験を行なえばもっとよい結果が得られると思われ 

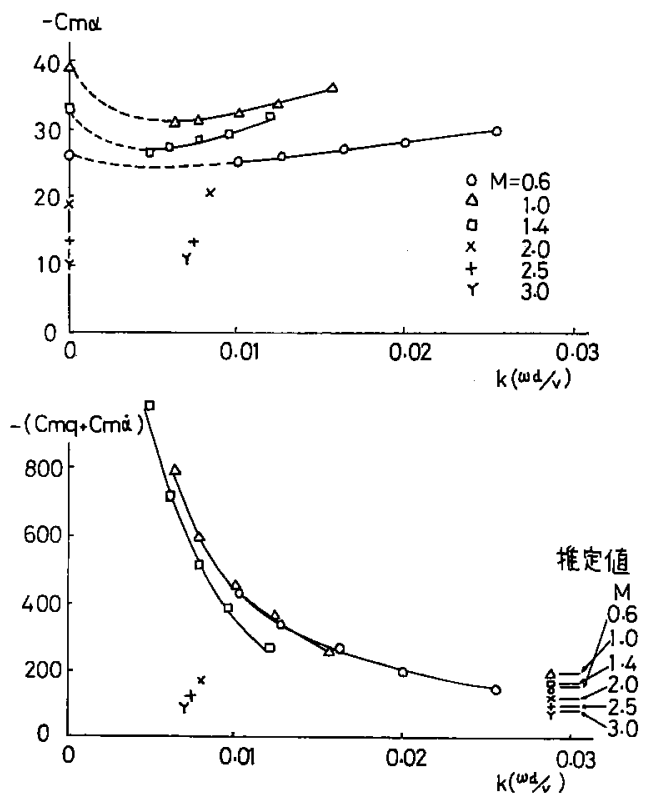

第 8 図 無次元掁動数化対する变化

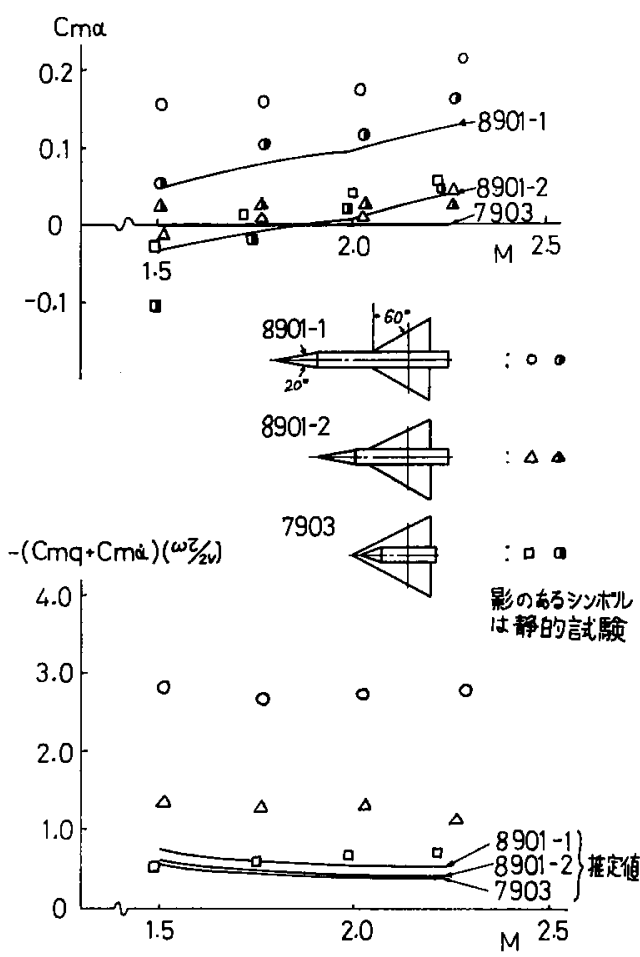

第 9 园 三角翼翼胴結合体の動的試驗

万。

第 9 図は胴体のある $60^{\circ}$ 後退角三角翼模型に対する 超音速での実験結果である．胴体は頭部が半頂角 $10^{\circ}$ の円錐でその他の部分は円柱である．との試験は前部 胴体の長短の影響を調べるために行なったあのであ る. 前部胴体を長くすると頭部に働く揚力のため空力
中心は前方に移動するから静安定微係数は不安定側に ずれる. との場合の基準点は全翼の中心にある.マッ 八数の増加に対しても $C_{m a}$ は十側へ移動している. 静的試験結果と動的試験結果を比ぺてみると前部䏨体 の短い模型については良く一致しているが他の模型で はやや開きがあり，動的試験結果が不安定側に表われ ている.

動安定微係数については前部胴体の影響は著しく， 理論的な予想とはかなり異なる．との推定値は，翼胴 結合体の揚力傾斜係数を翼単独, 胴体単独の揚力傾斜 係数から計算するのと同じ要領で，翼単独，胴体単独 の動安定微係数から計算したものである ${ }^{112}$ ．推定值と 実験結果の違いは種々考えられる. 推定值計算の際, 後部胴体の影響の評価，模型表面の丸み，かどの部分 の問題等があげられる．前部胴体のない模型の実験結 果は三角翼単独の推定值とほぼ一致しているといえ る. マッハ数に対する変化状況は全模型について推定 值と同じである.

次に強制回転法による横摇れ減衰係数の測定結果に ついて述へる．模型と内挿式天秤とを一体としたまま $X$ 軸まわりに回軽させると，旋転のため模型の右翼， 左翼で迎角が生じその符号は反対である．したがって 回転を停止させようとする方向に横摇れモーメントが 働き，そのモーメントを天秤で検出できる. 種々の回 転数に対するデータから横摇れ減衰係数 $C_{i p}$ が得られ る. との場合，左右翼に酒く揚力ベクトルの傾きの違 い等から生ずる偏摇れモーメントあ天秤で検出すれば adverse yaw 効果の $C_{n p}$ を求めることができる.

第 10 図は遷音速風胴における試験結果である. 模 型は頭部が ogive, 主翼，尾翼とも $1 / 4$ 弦線が $40^{\circ}$ の 後退角を持ち，テーパ比はともに0.5である. 図に示 すようにマッ八数の增加ととすに減衰微係数は増大す るが迎角が $6^{\circ}$ の場合は逆の傾向になる. また各マッ 八数において迎角 $2^{\circ}$ までは $-C_{\imath \triangleright}$ は増大し，その後

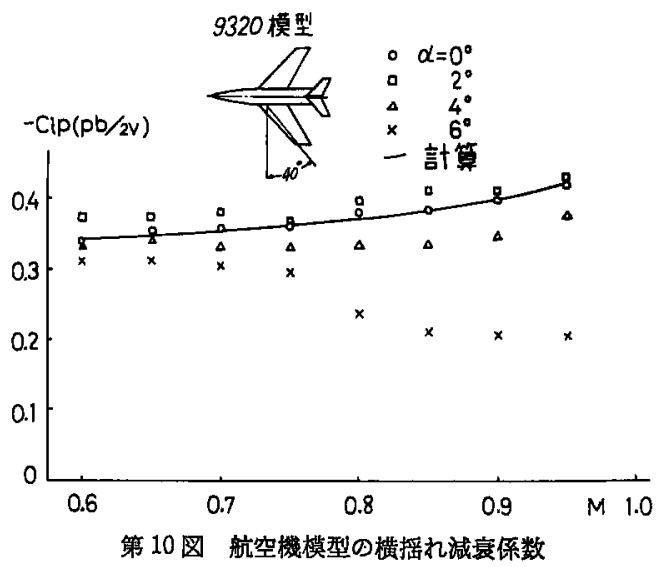




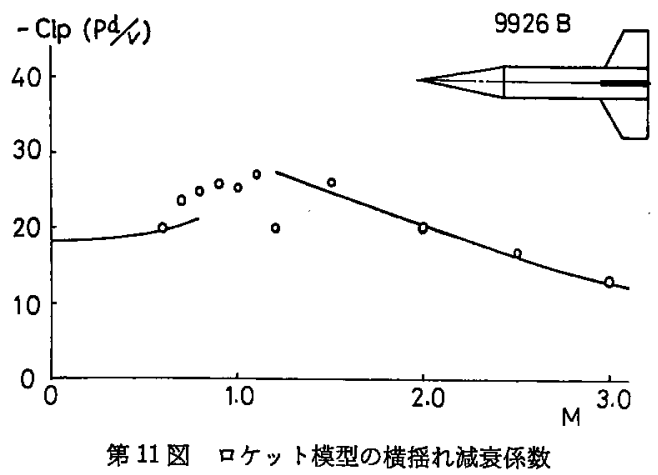

迎角增加とともに減少している. 推定值 ${ }^{11}$ は迎角零の 場合任対するあので実験結果之極めて良く一致してい る、この強制回転法の場合は，曲がりスティングを用 い，模型を一定迎角で安定軸系の $X$ 軸まわりに回転 させ，図のように迎角のある場合の $C_{t}$, 必要ならば $C_{n p}$ を容易に求めることができる，乙の方法をさらに 㹡張して同様な方法で縦摇れ，偏摇れ動安定微係数を 得ようとする試みあある

ロケット模型に対する横摇れ動安定試駼結果は第11 困に示される．迎角は零度の場合のみであるが推定值 に近い傾向を示し，特に $M \geqq 1.5$ では推定値とよく 一致している。

\section{5. 結 論}

（1）強制振動法によって動安定微係数を測定でき るが計測装置の一部を詳しく解折して，データに表わ れる譔差を求め，その修正法を示した．とれによって データの精度はよくなることがわかる。

（2）あるロケット模型の動安定試験を行ない，縦 摇孔動安定微係数は尾翼が $\times$ 状態の方が+状態の場合 より大きい結果を得た.

（3）前部胴体長をかえたある翼胴結合体の動安定 試験で緃摇れ動安定微係数は前部胴体長によって大き く影響をうけるととがわかった。

（4）強制回転による横摇れ動安定試験では極めて 良好な結果を得た．迎角のある場合のデータも曲がり
スティングを利用して容易に得られる.

終わりに，試験装置の設計，風胴試験にあたって常 に援助，協力して頂きました航空宇宙技術研究所の重 見部長を始め，䢩音速風胴第一，第二制御室，計測室， 超音速風胴制御，計湘室の諸氏に深く感謝します。

\section{文献}

1) C. J. Schueler, L. K. WARD and A.E. HodApp, Jr: Techniques for Measurement of Dynamic Stability Derivatives in Ground Test Facilities, AGARD ograph 121 (1967).

2）前田弘：風胴における機体の安定微係数の㨽定法，日 本航空学会誌, Vol. 8, No. 79 (1960), pp. 215 224.

3) R.P. Biflat and H. G. Wiley: Dynamic Longitudinal and Directional Stability Derivatives for a $45^{\circ}$ Sweptback-Wing Airplane Model at Transonic Speeds, NASA TM X-39 (1959).

4）高島一明，森原盛三，原亘利，北出大三，金成正好： 動安定微係数测定用風胴天秤について，航技研凅料， TM-106 (1967).

5) D. E. Hewes: Low-Subsonic Measurements of the Static and Oscillatory Lateral Stability Derivatives of a Sweptback-Wing Airplane Configuration at Angles of Attack from $-10^{\circ}$ to $90^{\circ}$, NASA MEMO 5-20-59 L (1959).

6) A. L. Braslow, H. G. Wiley and C.Q. Lfe: A Rigidly Forced Oscillation System for Measuring Dynamic-Stability Parameters in Transonic and Supersonic Wind Tunnels, NASA TN D-1231 (1962).

7）高島一明，桏原盛三，関根英夫：超音速風胴に扣ける 動安定微係数の測定，航技研報告発表予定.

8) 航空技術研究所：航空技術研究所 $2 \mathrm{~m} \times 2 \mathrm{~m}$ 僄音速風 胴の計画之構造，航技研報告 TR-25 (1962).

9) 空気力学第二部： $1 \mathrm{~m} \times 1 \mathrm{~m}$ 吹出式超音速風桐の計画 之構造，航技研報告 TR-29（1962）。

10) A. H. Sacks: Aerodynamic Forces, Moments, and Stability Derivatives for Slender Bodies of $\mathrm{Ge}$ neral Cross Section, NACA TN 3283 (1954).

11) USAF Stability and Control DATCOM, (1968) AFFDL Wright Patterson Air Force Base, OHIO.

12）小橋安次郎，河野長正，西武徳，宮沢政文：回枟式牛 安定测定装置による遷音速試験. 航技研報告 TR-196 (1970).

13) L. B. Schipf and M. Tobak: Results from a New Wind-Tunnel Apparatus for Studying Coning and Spinning Motions of Bodies of Revolution, AIAA J. Vol. 8, No. 11 (1970). 